\title{
Assessment of Development of Yuksom Gram Panchayat Unit in Sikkim using SWOT Model
}

Sushmita Chakraborty ${ }^{+*}$ and Dr Namita Chakma ${ }^{¥}$

\section{Abstract}

SWOT model is a technique to appraise strategies for rural development. This study aims to apply this model to examine the development of Yuksom Gram Panchayat Unit (GPU) of West district of Sikkim, India. To accomplish this analysis, internal factor evaluation (IFE) matrix and external factor evaluation matrix (EFE) were prepared to identify the critical and less important factors for development. Finally, a framework for strategy has been formulated by linking 'strengthopportunity' (SO) and 'weakness-threat' (WT) aspects. Results show mountain environment sustainability as the most agreed one (SO) and on the other hand, implementation of 'land bank scheme' and microfinance (WT) as the alternate planning strategies for the development of the Yuksom area.

Keywords: SWOT Analysis; 'Land Bank Scheme'; Microfinance; Sikkim

\footnotetext{
${ }^{\dagger}$ Research Scholar, Department of Geography, The University of Burdwan, Purba Bardhaman, 713104, West Bengal *Email: sushmita.chakraborty8@gmail.com

¥ Associate Professor, Department of Geography, The University of Burdwan, Purba Bardhaman, 713104, West Bengal, Email: namitachakma@gmail.com
} 


\section{Introduction}

Development of a region is a multidimensional concept, and it is one of the debated and critical issues in socio-economic research (Milenkovic et al., 2014). Economic growth and sustainable development are merely associated with the improvement of the quality of life (Sen 1987; UNDP, 1990; Dasgupta, 1993; Ghosh, 2011). For the socio-economic development of a particular region, human development remains the primary concern. According to Kundu (2009), "the problem of unequal access of different sections of the population to land, labour and capital market and also the provision of basic amenities including education and health service have been identified as major areas of concern in the country". The main aim of the present study is to assess the development of Yuksom Gram Panchayat Unit (GPU) of West district of Sikkim, India. It is noted that Sikkim is one of the eight states of North East India. The North-East council (NEC) of India was set up in 1971 with the primary purpose of the rapid growth of NorthEastern region (Bhandari and Kale, 2009). Sikkim, the 22nd state of Indian Union, is suffering from systematic balanced development and it has become utmost essential to develop the remote rural areas, the problems of which are mired in economic, social and political factors.

Notwithstanding, "the development strategies for any country are contingent upon the prevailing initial conditions, quality of human capital, geographical setting, political economy and government policies" (Chandna, 2016: pp. 114). This scenario is the same for rural areas of Sikkim. SWOT (strength, weakness, opportunities and threats) analysis is a useful technique for strategic management research (Sevkii et al., 2012) where ability of each factor used in the development and execution of long term planning strategies helps to achieve particular goal (Houben et al., 1999; Gao and Peng, 2011; Sevkii et al., 2012).

The central aim of this study is to analyse the development scenario of Yuksom GPU where the emphasis has been given to identifying the Strength, Weakness, Opportunity and Threat factors (SWOT) which affect development. The study also tries to formulate an alternative strategy for further development of this remote mountain village. Thus, SWOT analysis and the resultant discussion may help the researchers and the policymakers to identify the proper ordering of the strategies for action planning at a micro-level.

\section{The Study Area}

Sikkim, the beautiful Himalayan State comprises ofa population of 610,577 with areal coverage of 7096 sq. Km (Census of India, 2011). Yuksom $\left(27^{\circ} 22^{\prime} 24^{\prime \prime} \mathrm{N}, 88^{\circ} 13^{\prime} 15^{\prime \prime} \mathrm{E}\right)$ was the first capital of Sikkim in 1642 AD. The GPU consists of two villages, that is, Yuksam and Dubdi. The total area of the GPU is $11.5 \mathrm{sq}$. $\mathrm{Km}$. with a population of 2543 (Census of India, 2011). This area is mainly inhabited by the indigenous 'Bhutia', 'Lepcha' and 'Limboo' communities (Chakma and Chakraborty, 2018). The regional altitude of this GPU ranges between $1500-3000 \mathrm{~m}$. Yuksom is the gateway to the Kanchenjunga Biosphere Reserve in West district of Sikkim (Figures 1, 2 and 3).

\section{Objectives of the Study}

The present work has the following goals:

- To analyse the existing internal and external factors for the development of the study area; and

- To recommend strategies for the further development of the study area.

\section{Methods}

The present study is based on primary field survey where a total number of 200 respondents have been randomly selected from the whole GPU. A structured questionnaire has been used during the field survey. Both qualitative and quantitative research methods have been used in the study. Qualitative research methods include formal and informal interviews and focus group discussion (FGD). 


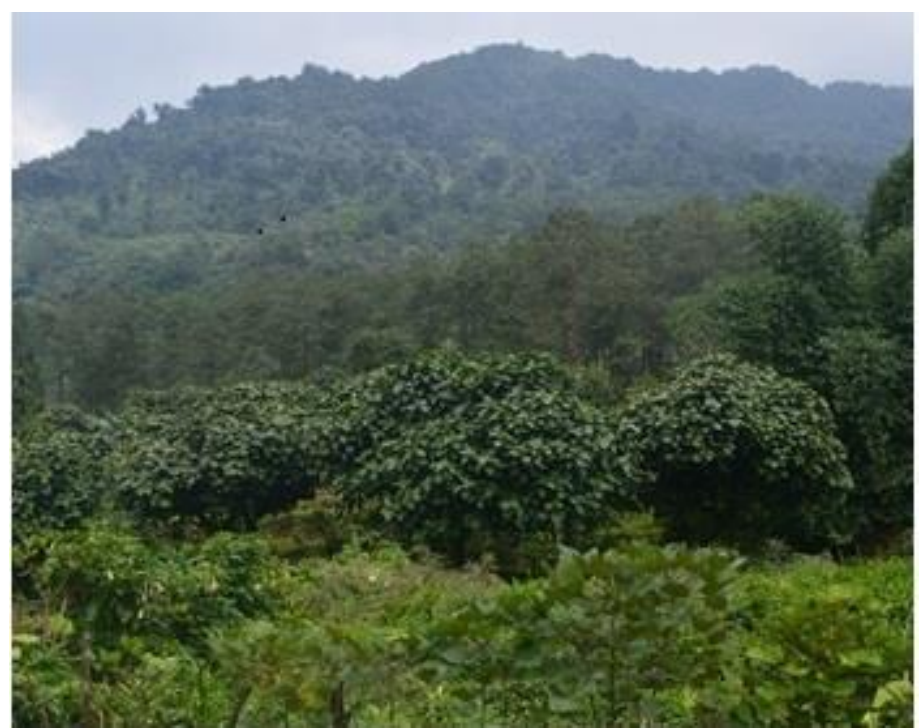

Figure 1: Kanchenjungha National Park, Yuksom Source: Authors

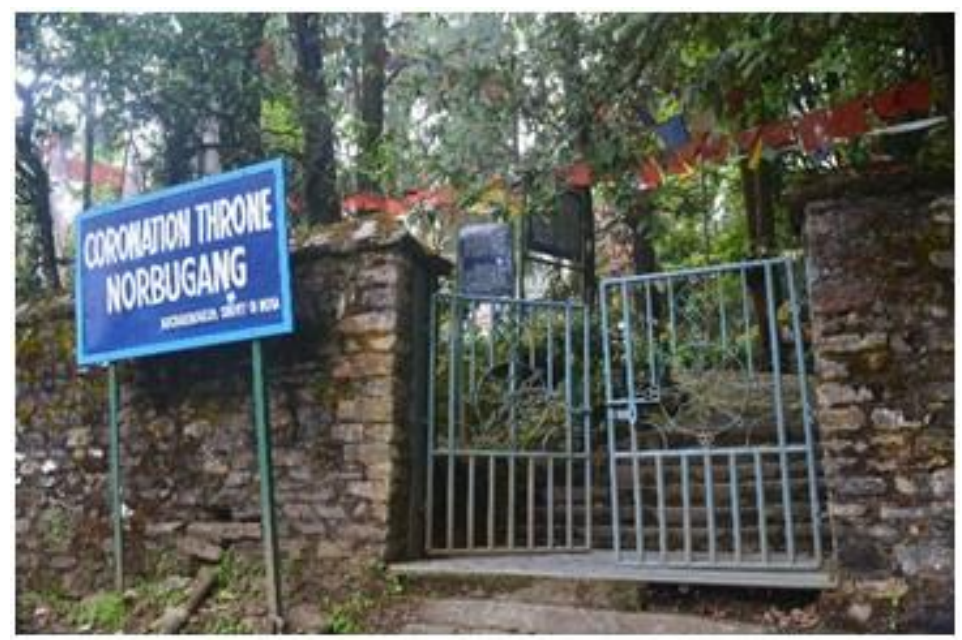

Figure 2: Heritage Site, Yuksom Source: Authors

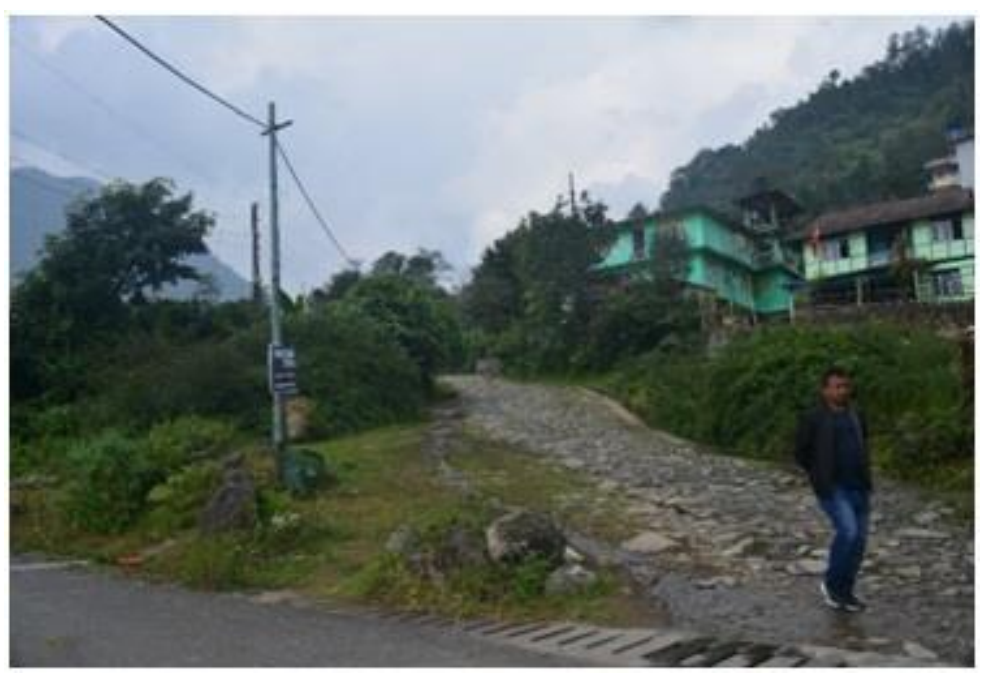

Figure 3: Trekking Trail, Yuksom Source: Authors 
To carry out the research, formal and informal interviews of 200 respondents in the GPU and four FGDs have been conducted. FGD is a crucial tool to execute a particular theme of research. Respondents of FGD were Government officials (1 FGD with the members of Yuksom Gram Panchayat Office), homestay owners of Yuksom GPU (1 FGD), local villagers of Khyongte and Ting Ting village of Yuksom GPU (1 FGD), tourists (1 FGDs) who visited the Yuksom. During the survey of individual households and Government office (Gram Panchayet Office), the respondents were requested to gather at certain place of Yuksom to formulate the FGDs. Tourists who stay in hotels and homestays were also requested to cooperate with our team for FGD. A team guide (facilitator) has been selected from our team and the team has developed a format to record the responses. Questions were asked about their perceptions, beliefs, attitudes, opinion or ideas regarding the present village development scenario, pull and push factors for development and further development strategies. Groups consisted of 8-12 people. Hindi and Nepali were main communication language. To analyse the interviewed data, debriefing was important and after the primary data collection, SWOT model (S-Strength, W-Weakness, O-Opportunity, TThreat) has been used to assess the development.

SWOT analysis can be used both qualitatively and quantitatively. In the case of quantitative methods, Statistical SWOT analysis technique has been applied. Weighted values have been given against strength, weakness, opportunities and threats factors. 13 Strength factors, 7 weakness factors, 5 opportunity factors and 4 threat factors have been identified through field survey.

The Strength factors are Well-developed education infrastructure (S1), High youth literacy rate (S2), Sufficient ASHA workers, medical practitioners and availability of adequate facilities of PHC (S3), Availability of maternity and child welfare centre (S4), Sufficient number of birth and death registration offices (S5), Tendency of service sector involvement of rural community (S6), Large landholding (S7),
Historical and cultural significance of the area (S8), Rural tourism development (S9), Road condition and transport vehicle frequency (S10), Sufficient nutritional centres (ICDS) (S11), Regular market and Kishan Mandi facility ensure the retailing and commercial activities (S12)Community participation in rural development programme is high (S13).

Weakness factors are Unequal implications of rural development schemes (W1), Lack of yearly health campaigning programmes (W2), Lack of sub-post offices in the whole GPU (W3), No private courier facilities (W4), Limited numbers of agricultural credit societies (W5), Limited numbers of self-help groups (SHG) (W6) and Non availability of ATM, commercial bank and cooperative banks (W7).

Opportunity factors are Set up of TB clinic (01), Establishment of public library (02), Establishment of more PCO (O3), Establishment of family welfare centres (04) and Implementation of housing development schemes in all the villages (05).

Threat factors are Landslide hazard during the rainy season (T1), Isolation of villages (T2), Low level of basic services (T3) and Water scarcity (T4).

The rating scale of all the four factors has been measured through perception survey. Lastly, the weighted score for each SWOT parameters has been calculated through multiplications of weighted values and rating scale. The weighted value for strength and opportunity range from 0.01 (not important) to 1.0 (very important) whereas, the weighted value for weakness and threats range from -0.01 (not important) to -1.0 (very important). On the other hand, the rating scale for four factors measuring importance is also measured through perception survey ranging 1-3. 1 designates minor and 3 for major.

SWOT analysis constitutes of few steps. Firstly, the internal factor evaluation and external factor evaluation matrix (IFE and EFE) have been prepared to identify the essential and less important factors. Secondly, a framework has been made for strategy development by linking 'strength-opportunity' (SO) and 'weakness- 
threat' (WT) aspects. SO strategy suggests using strength factor to enhance the opportunities of particular rural area. On the other hand, WT strategy suggests action planning to combat both weakness and threats (Bull et al., 2016). Quantitative strategic planning matrix (QSPM) has been used in the study. It is mainly used to highlight the systemic assessment of internal and external factors for rural development framework, the further scope of research, the performance of alternative planning strategies and decision upon a particular scope of action. Thus, this technique objectively selects the best strategy in an orderly manner for rural development (Ommani, 2011). Attractiveness score (AS) and total attractiveness score (TAS) are used in the QSPM matrix. AS suggests how each factor is attractive to each alternative planning strategy. Range of AS varies from 1 (not attractive) to 4 (highly attractive).TAS indicates the relative attractiveness of each factor and interrelated individual strategies. Finally, it leads to sum up attractiveness scores (AS) to total attractiveness score (STAS).

\section{Results and Discussion}

It is obtained from Table 1 that the historical and cultural significance (S8) are the main strengths of the area. As already stated above, Yuksom was the first capital of Sikkim; and it is indeed a place of cultural and historical significance, which manages to attract tourists from different parts of the world. The historical and cultural significance is associated with important trekking route (Dzongri-Goechala) which also attracts trekkers and tourists from all over the world and plays a significant role in the economic development of the area. Proper road connection and transport frequency (S10) from Pelling and Geyzing enhance the flow frequency of the tourists to Yuksom. The simultaneous effects of historic-cultural significance and road infrastructure from Pelling have made easy access for the tourists culminating rural tourism development (S9). The other necessary strength of the GPU includes the village infrastructure (education and available medical facilities), large landholding feasible for agricultural production, retail activities and community involvement.

Nevertheless, the GPU suffers from weaknesses too. For example, inadequate implementation of rural development schemes (W1) and lack of commercial facilities like ATM, commercial and co-operative banks (W7). Inadequate distribution and functioning of the rural development schemes (rural water security, agricultural and livestock development) among the villagers affect their standard of living and village infrastructure development. The inadequacies are more pronounced in the rural wards like Gufadara and Dubdi areas. On the other hand, lack of banks and ATM service facilities affect the villagers' daily life and tourists also.

External factors revealed future opportunities and threats to the study area. Table 2 shows that there exist opportunities to equal implications of social assistance schemes (05) in each village primarily rural housing programmes like 'Chief Minister's Rural Housing Mission' and 'Reconstruction of Earthquake Damaged Rural Houses'. There is also an opportunity to open family welfare centres (04). The findings however reveals that landslide hazards (T1) and low level of essential services in villages (T3) are the major threats on the way of development of the study area.

SWOT-analysis, this, helps to identify the strategic planning for any particular issue. Each SWOT theme consists of different planning strategy. Two planning strategies have been formulated in the present study on the basis of opinion survey of the locals and direct observation during the field study. First strategy consists of SO (strength-opportunity) analysis which uses the village strength to capitalise the opportunities. Second strategy links the WT (weakness-threat) which accentuates the action planning to reduce both internal weakness and external threat or challenges. WT strategy seems to be more effective in case of rural development through Quantitative Strategic Planning Matrix (QSPM). 
Table 1: Internal Factor Evaluation (IFE) Matrix of Yuksom GPU, Sikkim

\begin{tabular}{|c|c|c|c|c|}
\hline & Factors & $\begin{array}{l}\text { Weighted } \\
\text { Values }\end{array}$ & Rating & Score \\
\hline \multirow{13}{*}{$\begin{array}{l}\text { Strength } \\
\text { Factors }\end{array}$} & Well-developed education infrastructure (S1) & 0.24 & 3 & 0.72 \\
\hline & High youth literacy rate (S2) & 0.19 & 2 & 0.38 \\
\hline & $\begin{array}{l}\text { Sufficient ASHA workers, medicalpractitioners } \\
\text { and availability of adequate facilities of PHC } \\
\text { (S3) }\end{array}$ & 0.21 & 2 & 0.42 \\
\hline & $\begin{array}{l}\text { Availability of maternity and child welfare } \\
\text { centre (S4) }\end{array}$ & 0.17 & 1 & 0.17 \\
\hline & $\begin{array}{l}\text { Sufficient number of birth and death } \\
\text { registration offices (S5) }\end{array}$ & 0.04 & 1 & 0.04 \\
\hline & $\begin{array}{l}\text { Tendency of service sector involvement of } \\
\text { rural community (S6) }\end{array}$ & 0.34 & 2 & 0.68 \\
\hline & Large landholding (S7) & 0.21 & 3 & 0.63 \\
\hline & $\begin{array}{l}\text { Historical and cultural significance of the area } \\
\text { (S8) }\end{array}$ & 0.31 & 3 & 0.93 \\
\hline & Rural tourism development (S9) & 0.25 & 3 & 0.75 \\
\hline & $\begin{array}{l}\text { Road condition and transport vehicle } \\
\text { frequency (S10) }\end{array}$ & 0.3 & 3 & 0.9 \\
\hline & Sufficient nutritional centres (ICDS) (S11) & 0.13 & 1 & 0.13 \\
\hline & $\begin{array}{l}\text { Regular market and KishanMandi facility } \\
\text { ensure the retailing and commercial activities } \\
\text { (S12) }\end{array}$ & 0.12 & 1 & 0.12 \\
\hline & $\begin{array}{l}\text { Community participation in rural } \\
\text { development programme is high (S13) }\end{array}$ & 0.11 & 1 & 0.11 \\
\hline \multirow[t]{7}{*}{$\begin{array}{l}\text { Weakness } \\
\text { Factors }\end{array}$} & $\begin{array}{l}\text { Unequal implications of rural development } \\
\text { schemes (W1) }\end{array}$ & -0.39 & 2 & -0.78 \\
\hline & $\begin{array}{l}\text { Lack of yearly health campaigning programmes } \\
\text { (W2) }\end{array}$ & -0.36 & 1 & -0.36 \\
\hline & Lack of sub-post offices in the whole GPU (W3) & -0.29 & 1 & -0.29 \\
\hline & No private courier facilities (W4) & -0.29 & 1 & -0.29 \\
\hline & $\begin{array}{l}\text { Limited numbers of agricultural credit societies } \\
\text { (W5) }\end{array}$ & -0.36 & 1 & -0.36 \\
\hline & $\begin{array}{l}\text { Limited numbers of self-help groups (SHG) } \\
\text { (W6) }\end{array}$ & -0.28 & 1 & -0.28 \\
\hline & $\begin{array}{l}\text { Non availability of ATM, commercial bank and } \\
\text { co-operative banks (W7) }\end{array}$ & -0.37 & 2 & -0.74 \\
\hline
\end{tabular}




\begin{tabular}{|c|c|c|c|c|}
\hline & Factors & $\begin{array}{l}\text { Weighted } \\
\text { Values }\end{array}$ & Rating & Score \\
\hline \multirow{5}{*}{$\begin{array}{l}\text { Opportunity } \\
\text { Factors }\end{array}$} & Set up of TB clinic (01) & 0.39 & 2 & 0.78 \\
\hline & Establishment of public library (O2) & 0.32 & 1 & 0.32 \\
\hline & Establishment of more PCO (O3) & 0.29 & 2 & 0.58 \\
\hline & Establishment of family welfare centres (04) & 0.35 & 3 & 1.05 \\
\hline & $\begin{array}{l}\text { Implementation of housing development } \\
\text { schemesin all the villages (05) }\end{array}$ & 0.47 & 3 & 1.41 \\
\hline \multirow{4}{*}{$\begin{array}{l}\text { Threat } \\
\text { Factors }\end{array}$} & Landslide hazard during the rainy season (T1) & -0.24 & 3 & -0.72 \\
\hline & Isolation of villages (T2) & -0.29 & 1 & -0.29 \\
\hline & Low level of basic services (T3) & -0.22 & 2 & -0.44 \\
\hline & Water scarcity (T4) & -0.42 & 3 & -1.26 \\
\hline
\end{tabular}

Strategy 1: Strength-Opportunity (SO) factors highlight the following strategy for Yuksom GPU:

- (SO1): Availability of medical facilities remain a strength for Yuksom. Therefore, there exists an opportunity to develop 'Family Welfare Centre' for the improvement of reproductive health, paediatrics, maternal health which are essential to maintain the health system in rural areas.

- (SO2): There are opportunities to make mountain environment more sustainable for villagers, floras and faunas, and tourists by encompassing some environment-friendly strategies like waste management, plastic recycling, sanitation management and use of biodegradable cane baskets to meet the requirement of the dustbin.

- (SO3): Involvement of the villagers in the trading business may be more beneficial for their economic growth.

Respondent's opinion reveals that $\mathrm{SO} 2$ is highly supported by majority of the villagers (80\%), followed by SO3 and SO1 (Figure 4).

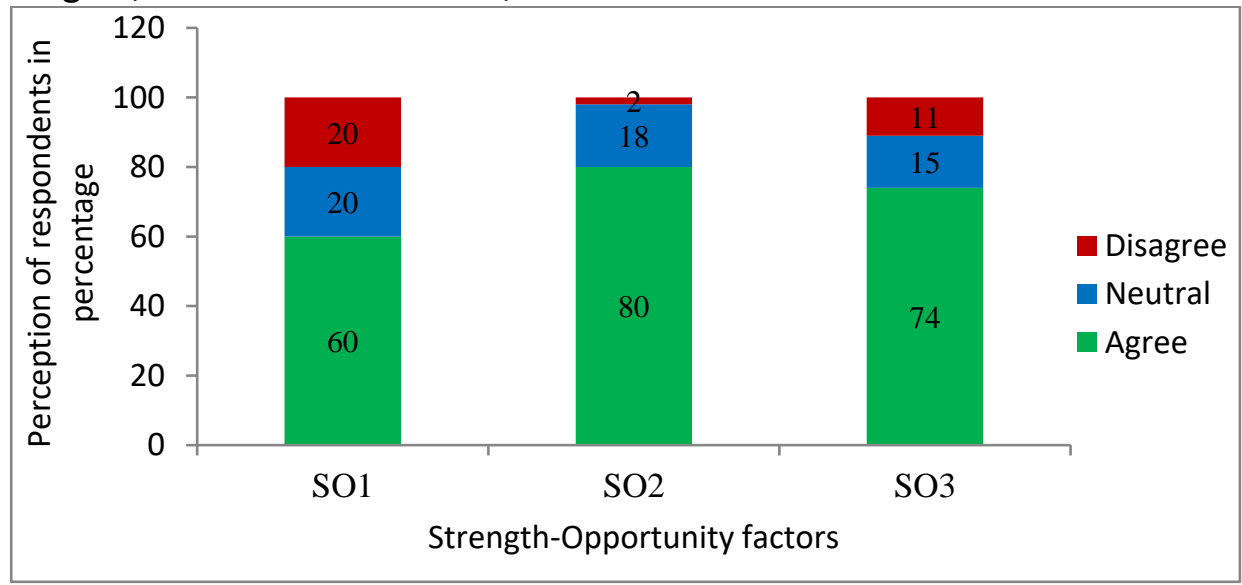

Figure 4: Perception of the Respondents for Strength-opportunity Factors in Yuksom GPU. Source: Field Survey, 2018

Strategy 2 seeks to formulate the QSPM (Table 3) to find out alternative action planning strategies in an orderly manner which can reduce the weakness and threat of the concerned GPU. The alternative actions planning by linking WT are as follows:

- (WT1): Proper and parallel implementation of 'Land bank 
scheme' may be beneficial for socioeconomic development of the landless labour, especially in Gufadaraarea in Yuksom GPU who remain isolated for a long time.

- (WT2): Development of microfinance institutions for underprivileged villagers, including women.

- (WT3): To reduce water scarcity in village areas it is needed to adopt different strategies like water harvesting through maintenance of surface water bodies, improvement of the recharge capacity of the springs and repairing of pipelines, and roof water harvesting. All these may enable the villagers to get adequate water in the dry season.

- (WT4): Satisfactory implementation of social assistance schemes, especially in the remoteDubdi village.

- (WT5) Lack of agricultural credit society may be replaced by providing 'farm loan waivers' to the villagers during crop failure or crop damage.

\begin{tabular}{|c|c|c|c|c|c|c|c|c|c|c|c|}
\hline \multirow[t]{2}{*}{ Factors } & \multirow[t]{2}{*}{ Scores } & \multicolumn{2}{|c|}{ WT1 } & \multicolumn{2}{|c|}{ WT2 } & \multicolumn{2}{|c|}{ WT3 } & \multicolumn{2}{|c|}{ WT4 } & \multicolumn{2}{|c|}{ WT5 } \\
\hline & & AS & TAS & AS & TAS & AS & TAS & AS & TAS & AS & TAS \\
\hline S1 & 0.72 & 1 & 0.72 & 3 & 2.16 & 1 & 0.72 & 3 & 2.16 & 1 & 0.72 \\
\hline $\mathrm{S} 2$ & 0.38 & 2 & 0.76 & 2 & 0.76 & 2 & 0.76 & 1 & 0.38 & 2 & 0.76 \\
\hline S3 & 0.42 & 1 & 0.42 & 1 & 0.42 & 1 & 0.42 & 1 & 0.42 & 1 & 0.42 \\
\hline S4 & 0.17 & 1 & 0.17 & 1 & 0.17 & 1 & 0.17 & 1 & 0.17 & 1 & 0.17 \\
\hline $\mathrm{S} 5$ & 0.04 & 1 & 0.04 & 1 & 0.04 & 1 & 0.04 & 1 & 0.04 & 1 & 0.04 \\
\hline S6 & 0.68 & 2 & 1.36 & 4 & 2.72 & 1 & 0.68 & 3 & 2.04 & 3 & 2.04 \\
\hline S7 & 0.63 & 4 & 2.52 & 1 & 0.63 & 4 & 2.52 & 3 & 1.89 & 4 & 2.52 \\
\hline S8 & 0.93 & 1 & 0.93 & 1 & 0.93 & 1 & 0.93 & 1 & 0.93 & 1 & 0.93 \\
\hline S9 & 0.75 & 3 & 2.25 & 1 & 0.75 & 3 & 2.25 & 2 & 1.5 & 2 & 1.5 \\
\hline $\mathrm{S} 10$ & 0.9 & 1 & 0.9 & 1 & 0.9 & 1 & 0.9 & 1 & 0.9 & 1 & 0.9 \\
\hline $\mathrm{S} 11$ & 0.13 & 1 & 0.13 & 2 & 0.26 & 1 & 0.13 & 1 & 0.13 & 1 & 0.13 \\
\hline $\mathrm{S} 12$ & 0.12 & 2 & 0.24 & 1 & 0.12 & 1 & 0.12 & 1 & 0.12 & 3 & 0.36 \\
\hline S13 & 0.11 & 2 & 0.22 & 4 & 0.44 & 2 & 0.22 & 3 & 0.33 & 4 & 0.44 \\
\hline W1 & -0.78 & 3 & -2.34 & 4 & -2.34 & 4 & -3.12 & 4 & -2.34 & 3 & -2.34 \\
\hline W2 & -0.36 & 1 & -0.36 & 1 & -0.36 & 1 & -0.36 & 1 & -0.36 & 1 & -0.36 \\
\hline W3 & -0.29 & 1 & -0.29 & 1 & -0.29 & 1 & -0.29 & 1 & -0.29 & 1 & -0.29 \\
\hline W4 & -0.29 & 1 & -0.29 & 1 & -0.29 & 1 & -0.29 & 1 & -0.29 & 1 & -0.29 \\
\hline W5 & -0.36 & 2 & -0.72 & 2 & -1.44 & 1 & -0.36 & 2 & -0.72 & 4 & -1.44 \\
\hline W6 & -0.28 & 1 & -0.28 & 4 & -1.12 & 1 & -0.28 & 2 & -0.56 & 1 & -0.28 \\
\hline W7 & -0.74 & 1 & -0.74 & 1 & -0.74 & 1 & -0.74 & 1 & -0.74 & 1 & -0.74 \\
\hline 01 & 0.78 & 1 & 0.78 & 1 & 0.78 & 1 & 0.78 & 1 & 0.78 & 1 & 0.78 \\
\hline $\mathrm{O} 2$ & 0.32 & 1 & 0.32 & 1 & 0.32 & 1 & 0.32 & 1 & 0.32 & 1 & 0.32 \\
\hline $\mathrm{O3}$ & 0.58 & 1 & 0.58 & 1 & 0.58 & 1 & 0.58 & 1 & 0.58 & 1 & 0.58 \\
\hline $\mathrm{O4}$ & 1.05 & 1 & 1.05 & 2 & 2.1 & 1 & 1.05 & 1 & 1.05 & 2 & 2.1 \\
\hline 05 & 1.41 & 4 & 5.64 & 3 & 4.23 & 2 & 2.82 & 4 & 1.41 & 1 & 1.41 \\
\hline $\mathrm{T} 1$ & -0.72 & 2 & -1.44 & 1 & -0.72 & 3 & -2.16 & 1 & -0.72 & 2 & -1.44 \\
\hline $\mathrm{T} 2$ & -0.29 & 4 & -1.16 & 2 & -0.58 & 3 & -1.16 & 4 & -1.16 & 3 & -1.16 \\
\hline T3 & -0.44 & 4 & -1.76 & 2 & -0.88 & 4 & -1.76 & 4 & -1.76 & 2 & -0.88 \\
\hline $\mathrm{T} 4$ & -1.26 & 1 & -1.26 & 1 & -1.26 & 4 & -5.04 & 1 & -1.26 & 1 & -1.26 \\
\hline STAS & & & 8.39 & & 8.29 & & -0.15 & & 4.95 & & 5.64 \\
\hline Priority & & & 1 & & 2 & & 5 & & 4 & & 3 \\
\hline
\end{tabular}


The result, as illustrated in Table 3 demonstrates that WT1 and WT2 are high prioritised strategies. Landbank scheme was initiated by the state government of Sikkim in 1997 to provide 0.25 acre of land for construction of dwelling houses, cultivation and other allied activities to the landless people. It has been found that people residing in the Gufadara area are landless and therefore, needs to be taken care of. WT2 strategy suggests strengthening of microfinance in Yuksom. During the field survey, it is found that most of the poor villagers are managing hard to mobilise resources to develop their economic condition. Financial services could enable the villagers to accelerate their income and influence their initiatives (Vetrivel and Kumarmangalam, 2010). Though the villagers have given some subsidy from the government but these are not sufficient. As in the study area, where exists a lack of formal employment options, most of the villagers are 'non bankers'. These factors force them to borrow money from the local moneylenders at high-interest rates. Thus different microfinance institutions may help the local residents. Another important prioritised strategy includes 'farm loan waivers' and water management for Dubdi village. Villagers often suffer from the lack of getting a loan for crop production and during crop failure; thus, 'farm loan waivers' may be a viable option for them. Villagers of Dubdi village are also suffering from water scarcity, especially in dry seasons.

\section{Conclusion}

The result, as illustrated in Table 3 demonstrates that WT1 and WT2 are high prioritised strategies. Landbank scheme was initiated by the state government of Sikkim in 1997 to provide 0.25 acre of land for construction of dwelling houses, cultivation and other allied activities to the landless people. It has been found that people residing in the Gufadara area are landless and therefore, needs to be taken care of. WT2 strategy suggests strengthening of microfinance in Yuksom. During the field survey, it is found that most of the poor villagers are managing hard to mobilise resources to develop their economic condition. Financial services could enable the villagers to accelerate their income and influence their initiatives (Vetrivel and Kumarmangalam, 2010). Though the villagers have given some subsidy from the government but these are not sufficient. As in the study area, where exists a lack of formal employment options, most of the villagers are 'non bankers'. These factors force them to borrow money from the local moneylenders at high-interest rates. Thus different microfinance institutions may help the local residents. Another important prioritised strategy includes 'farm loan waivers' and water management for Dubdi village. Villagers often suffer from the lack of getting a loan for crop production and during crop failure; thus, 'farm loan waivers' may be a viable option for them. Villagers of Dubdi village are also suffering from water scarcity, especially in dry seasons.

\section{References}

Bhandari, L. and Kale, S. (2009). The North East and Sikkim: Performance, Facts and Figures. Dorling Kindersley (India) Pvt. Ltd. New Delhi: India

Bull, J.W., Jobstvogt, N., Bohnke-Henrichs, A., Mascarenhas, A., Sitas, N., Baulcomb, C., Lambini, C.K., Rawlins, M., Baral, H., Zahringer, J., Carter-Silk, E., Balzan, M.V., Kenter, J.O, Hayha, T., Petz, K., and Koss, R. (2016).

Strength, Weakness, Opportunities and Threats:

A SWOT Analysis for Ecosystem Service

Framework. Ecosystem Service. 17, 99-111.

Retrieved on 01 October 2019

from,http://www.elsevier.com/locate/ecoser

Census of India, 2011. (2011). New Delhi: Office of the Registrar General \& Census

Commissioner, India, Ministry of Home Affairs, Govt. of India. Retrieved on 01 October 2019 from http://censusindia.gov.in

Chakma, N. and Chakraborty, S. (2018). Perspective on Sanskritisation of Sikkim, In Discourses on Human-Nature Interaction in Eastern India, (Biswas, B. edited), Rhito Publication, Kolkata

Chandna, R. C. (2016). Regional Planning and Development. New Delhi; Kalyani Publishers 
Dasgupta, P. (1993). An Inquiry into Well-being and Destitution. Clarendon Press, Oxford

Gao, G-Y \& Peng, D-H. (2011). Consolidating SWOT Analysis with Non-Homogeneous Uncertain Preference Information. Knowledge Based System. 24(6). 796-808, doi:10.1016/j.knosys.2011.03.001

Ghosh, M. (2011). Regional Disparities in Education, Health and Human Development in India. Indian Journal of Human Development. 5(1). Retrieved on 12 November 2019 from http://isid.org.in/pdf/WP1205.pdf

Houben, G., Lemie, K., Vanhoof, K. (1999). A Knowledge Based SWOT Analysis System as an Instrument for Strategic Planning in Small and Medium Sized Enterprises. Decision Support System. 26(2). 125-135, doi10.1016/S01679236(99)00024-X

Kundu, A. (2009). Achiving Diversity in Socio Economic Space: An alternative Strategy of Intervention through the Diversity Index. Indian Journal of Human Development. 3(2), doi 10.1177/0973703020090206

Milenkovic, N. Vukmirovic, J. Bulajic, M and Radojicic, Z. (2014). A Multivariate Approach in Measuring Socio Economic Development of MENA Countries. Economic Modelling. 38, pp 604-608.

Ommani, A. R. (2011). Strength, Weakness, Opportunities and Threats (SWOT) Analysis for Farming System Businesses Management: Case of Wheat Farmers of Shadervan District, Shoushter Township, Iran. African Journal of Business Management. Vol. 5 (22), pp-9448-
9454. Retrieved on 22 May 2019 from, http://www.academicjournal.org/AJBM

Sen, A. K. (1987). Standard of Living. Cambridge University Press. New York

Sevkii, M., Oztekin, A., Uysal, O., Torlak, G., Turkyilmaz A., Delen, D. (2012). Development of Fuzzy ANP based SWOT Analysis for Airline Industry in Turkey. Expert System Application. 39(1), 14-24. Retrieved on 21 May 2019 from https://research.nu.edu.kz/en/publications/dev elopment-of-a-fuzzy-anp-based-swot-analysisfor-the-airline-in

United Nation Development Programme (UNDP). (1990). Human Development Report 1990, Oxford University Press, New York

Vetrivel, S. C and Kumarmangalam, S.C. (2010). Role of Microfinance Institutions in Rural Development. International Journal of Information Technology and Knowledge Management. 2(2), 435-441. Retrieved on 17 June 2019 from, http://www.iari.res.in/files/Divisions/Role\%20o f\%20microfinance\%20institutions\%20in\%20rura I\%20development_SC\%20vetrivel\%20IJITKM.pd $\mathrm{f}$

\section{Acknowledgements}

The authors express their sincere gratitude to the Indian Council of Social Science Research (ICSSR), New Delhi, Government of India for the financial support. The authors are also thankful to the villagers of the Yuksom GPU for their cordial assistance during the field visit. The authors also express thanks to the anonymous reviewers for their sincere efforts. 